\author{
ZASADA PAŃSTWA PRAWA \\ W KONSTYTUCJI REPUBLIKI CZESKIEJ \\ (KILKA UWAG Z PUNKTU WIDZENIA \\ DOŚWIADCZENIA POLSKIEGO)
}

\begin{abstract}
Streszczenie. Niniejsze rozważania poświęcone są zawartej w tekście Konstytucji Republiki Czeskiej z 1992 roku zasadzie demokratycznego państwa prawnego: sposobowi konstytucyjnego ujęcia tej zasady, jej gwarancjom i ochronie, jaką konstytucja udziela istocie państwa prawnego oraz konsekwencjom takiej regulacji, zarówno dla życia społecznego i politycznego, jak i dla rozwoju doktryny prawa konstytucyjnego w tym zakresie. Szczególne znaczenie ma bowiem - obok deklaracji, że Republika Czeska jest demokratycznym państwem prawa (art. 1, ust. 1) - dodatkowe zastrzeżenie, iż w konstytucji nie mogą być dokonywane zmiany naruszające istotę tej zasady (tzw. klauzula wieczności), ani w tym kierunku interpretowane normy prawne (art. 9 ust. 2 i 3). Ponadto poddane zostały analizie także współgrające z tą zasadą inne przepisy konstytucji, zwłaszcza zastrzeżenie, iż podejmując decyzje większość respektuje prawa mniejszości (art. 6) oraz wyrażone expressis verbis obywatelskie prawo do oporu (art. 23 Karty podstawowych praw i wolności).
\end{abstract}

Słowa kluczowe: zasada państwa prawa, Konstytucja Republiki Czeskiej z 1992 roku, Konstytucja RP z 1997 roku, prawo do oporu, obywatelskie nieposłuszeństwo.

W niniejszym zbiorze opracowań, przygotowanych przez czeskich i polskich autorów, poświęconym omówieniu problematyki czeskiego konstytucjonalizmu z okazji 25-lecia uchwalenia Konstytucji Republiki Czeskiej, znajduje się tekst M. Tomoszka (2018), poświęcony konstytucyjnemu ujęciu i - co ważne - doktrynalnej interpretacji znaczenia, jakie zasada demokratycznego państwa prawnego ma dla praktyki konstytucyjnej w Republice Czeskiej. Ta bardzo wnikliwa i rzetelna analiza, oparta na znakomitej znajomości czeskiej i europejskiej doktryny oraz orzecznictwa konstytucyjnego, wzbogaca polską wiedzę nie tylko o informację, jak zasada państwa prawnego jest rozumiana i traktowana u naszych sąsiadów, ale także, jakie ma ona uniwersalne oblicze w demokratycznym państwie. I jak jej ujęcie konstytucyjne w Republice Czeskiej mogłoby się przekładać na sytuację w innym kraju.

Dlatego też wydaje się interesujące, aby podejmując problematykę państwa prawnego w konstytucji czeskiej, spojrzeć na nią z polskiego punktu widzenia. Nieco mniej uniwersalnego i doktrynalnego, a także bez elementu analizy

* Uczelnia Lazarskiego, Wydział Prawa i Administracji, Katedra Prawa Konstytucyjnego, mkjarosz@gmail.com. 
tamtejszej praktyki konstytucyjnej, bo w tym zakresie należy odesłać czytelnika do wspomnianego tekstu, ale dlatego, że praktyka konstytucyjna w Polsce, zwłaszcza w obecnym czasie, w znacznej mierze koncentruje uwagę społeczną, i rozważania doktrynalne, na problemach państwa prawnego i jego składników. I to właśnie w takiej sytuacji łatwiej dostrzec pewne niuanse wskazujące, że w konstytucji czeskiej i w konstytucji polskiej, mimo zachowania w nich obu deklaracji demokratycznego państwa prawnego, jako podstawowej zasady ustrojowej, podejście do niej wydaje się zróżnicowane. I nie chodzi tu o generalną treść tej zasady, to znaczy o te cechy ustroju politycznego (i społecznego) państwa, które powszechnie uznawane są za przesądzające o jego charakterze, jako demokratycznego państwa prawa. W Polsce zresztą „odkodowanie” składników tej zasady zaczęło się bardzo wcześnie i to równolegle - w teorii i w praktyce orzeczniczej Trybunału Konstytucyjnego, który otrzymał tę zasadę, jako wzorzec orzeczniczy, w grudniu 1989 roku, a więc jeszcze w czasie obowiązywania konstytucji z 1952 roku. A to znaczy, że jej wartość można było w ówczesnych warunkach liczyć w dwójnasób, bo przepisy tamtej konstytucji, mimo już wcześniejszych jej zmian (z 7.04.1989), rozpoczynających transformację po Okrągłym Stole, wciąż jeszcze nie zawierały większości standardów państwa prawnego. Kiedy zatem uchwalano Konstytucję RP z 1997 roku, zasada demokratycznego państwa prawnego była już w doktrynie i orzecznictwie polskim mocno utrwalona, opisana, i w polskim prawie zakorzeniona (Morawska 2003).

Jest oczywiście interesujące analizowanie obecności zasady państwa prawnego w konstytucji danego kraju przez pryzmat jego zasad podstawowych, instytucji, procedur, a przede wszystkim praw i wolności oraz ich gwarancji. Taka analiza może prowadzić do wniosku, że dane państwo ma wszelkie przesłanki do uznania go za demokratyczne państwo prawne, nawet gdyby sama ta zasada nie została $\mathrm{w}$ konstytucji wysłowiona expressis verbis. Można w takiej analizie zastanawiać się, czy suma tych konstytucyjnych cech ustroju, które uważa się za składniki standardowe państwa demokratycznego, jest wystarczająca lub czy nie ma wśród nich elementów przeczących tezie o funkcjonowaniu tam państwa prawa. Ale analiza taka wymagałaby też uzupełnienia o informacje pozaprawne, np. historyczne, o zasady wynikające np. z demokratycznej tradycji państwa, a bezwzględnie o praktykę konstytucyjną, wskazującą jak zasady konstytucyjne realizowane są w przepisach prawnych niższej rangi, w orzecznictwie sądowym, w praktyce administracyjnej i wielu innych przejawach życia społecznego i politycznego. Taka analiza w odniesieniu do ustrojowych zasad zawartych w konstytucji czeskiej, zwłaszcza wzbogacona o praktykę, byłaby wielce interesująca, choćby ze względu na rodowód tej konstytucji i rodowód samej Republiki Czeskiej, które (i Republika i jej konstytucja) uporać się musiały - i zostało uczynione to $\mathrm{z}$ najwyższej próby poszanowaniem zasad demokratycznych $-\mathrm{z}$ podziałem państwa, zakończeniem bytu federacji czesko-słowackiej, powołaniem dwu państw suwerennych. 
I choć w kontekście państwa prawnego byłoby to niezwykle interesujące, jednak w tym, z konieczności stosunkowo krótkim opracowaniu, nie o tych aspektach demokratycznego państwa prawa w czeskiej konstytucji będzie mowa. Chodzi bowiem o kwestię specyficzną, a mianowicie o sposób uregulowania tej zasady i konsekwencje, jakie to może rodzić dla jej rozumienia i przestrzegania. To z tego powodu pewne istotne elementy regulacji tej zasady w Konstytucji Republiki Czeskiej zmuszają do refleksji nad celowością, czy wręcz trafnością, takiego właśnie konstytucyjnego podejścia, nawet może nie tyle do samej deklaracji tej zasady jako takiej, ile do gwarancji jej stabilnej egzystencji jako bazy ustroju państwa. Zwłaszcza gdy okazują swe pozytywne oblicze nawet nie wtedy, kiedy jest pewność, że państwo, jego instytucje i w efekcie jego prawo, funkcjonują w sposób zgodny ze standardami państwa demokratycznego, ale właśnie wtedy, gdy pojawia się podejrzenie, że tak nie jest. I to stanowi punkt wyjścia do spojrzenia na czeską zasadę państwa prawnego z polskiego punktu widzenia. Stąd właśnie kilka poniższych uwag.

1.

Konstytucję Republiki Czeskiej otwiera deklaracja zasady państwa prawnego. Art. 1 powiada: „Republika Czeska jest suwerennym, jednolitym i demokratycznym państwem prawa opartym na poszanowaniu praw i wolności człowieka i obywatela" (cyt. wg Konstytucja Republiki..., 2011, 191). Tę generalną deklarację, wyrażającą zresztą pewne istotne priorytety, rozwijane w kolejnych przepisach rozdziału I, zatytułowanego „Zasady podstawowe”, uzupełnia w szczególny sposób art. 9, wskazujący w ust. 1, iż zmian konstytucji dokonuje się „tylko w drodze ustaw konstytucyjnych", ale ponadto - co tu istotniejsze - przynoszący w dalszej części ważne treści. Po pierwsze więc w ust. 2 konstytucja ustanawia tzw. przepis o niezmienności (nazywany też klauzulą wieczności), a mianowicie formułuje zasadę, iż ,[z]miany ingerujące $\mathrm{w}$ istotę demokratycznego państwa prawnego są niedopuszczalne”, zaś w ust. 3 dodaje, że „[i]nterpretacja norm prawnych nie może prowadzić do ograniczenia lub zagrożenia zasad państwa demokratycznego".

Art. 1 jest fundamentalną deklaracją ustrojową Konstytucji czeskiej, jaką zawiera też (w art. 2) polska Konstytucja, o czym już wyżej wspomniano. Przy okazji można zwrócić uwagę, że w Republice Czeskiej bazą dla państwa prawa jest „poszanowanie praw i wolności człowieka i obywatela”, podczas gdy w Polsce jest nią "zasada sprawiedliwości społecznej". Czy ta różnica jest merytorycznie znacząca i czy może wynika $z$ owych trzech lat dzielących moment wprowadzenia zasady do katalogu zasad podstawowych, a w związku z tym z etapu transformacji lub istotnych wówczas okoliczności społecznych (chociaż Konstytucja RP z 1997 roku powtórzyła tę formułę), czy też jest to pewna doktrynalna specyfika kraju? To są jednak tylko uwagi na marginesie, bo nie jest intencją autorki 
niniejszego tekstu wnikanie w kwestie merytoryczne, niemniej do sprawy jeszcze się krótko nawiązuje w dalszych rozważaniach. W literaturze czeskiej, w komentarzu do art. 1, podkreśla się, że konstytucja nie definiuje wprost pojęcia państwa prawnego, ale przepis ma przede wszystkim w swej treści przesłanie, iż państwo stanowi prawo $i$ jest tym prawem przede wszystkim samo związane, że wiąże je z cechą państwa demokratycznego, wskazuje na trwałość demokracji, zaś powiązanie z prawami i wolnościami - wyznacza obowiązek ich ochrony (Klíma a kol. 2009, Komentár $k$ Ustave..., 44, pkt. 20, 21). Na fakt związania państwa prawem przezeń stanowionym zwracają uwagę także inni autorzy, wskazując w powiązaniu z tym przesłaniem także dalsze przepisy konstytucji, m.in. art. 2 ust. 4 wskazujący na granicę uprawnień państwa w konfrontacji z wolnością obywatela (Pavlíček a kol. 2015, 377).

Wspomniany art. 9 ust. 2 stanowi już jednak inną kategorię przepisów niż sama deklaracja charakteru państwa jako demokratycznego państwa prawa. Po pierwsze dlatego, że wprowadza zasadę, iż konstytucja zawiera pewne regulacje niezmienne, po drugie - bo wzmacnia zasadę wyrażoną $\mathrm{w}$ art. 1, zakazując ingerencji w jej istotę (Klíma a kol. 2009, Komentár k Ustave..., 108). Niewątpliwie w pierwszym rzędzie wskazuje to na intencję ustrojodawcy zakazu usunięcia samej zasady, ale ponadto nakazuje weryfikację wszelkich zmian konstytucyjnych z punktu widzenia ich ewentualnej ingerencji w jakiekolwiek inne przepisy, realizujące standardy państwa prawnego. Tę zasadę pogłębia ust. 3 art. 9, stanowiąc, że: ,[i]nterpretacja norm prawnych nie może prowadzić do ograniczenia lub zagrożenia państwa demokratycznego"1. Mówiąc krótko, w konsekwencji konstytucja zabrania nie tylko wycofania się z zasady państwa prawnego, ale także wprowadzenia do innych konstytucyjnych treści takich zmian, które naruszałyby elementy składowe tej zasady, a wreszcie - takiej interpretacji jej przepisów (norm prawnych), które by tej zasadzie zagrażały generalnie lub choćby przez jej ograniczenie.

Jest oczywiste, że wprowadzenie do konstytucji tego rodzaju przepisów, jak czyni to art. 9 ust. 2 i 3 Konstytucji Republiki Czeskiej, wywoływać musi szereg konsekwencji na wielu płaszczyznach. Po pierwsze, co do charakteru tzw. przepisów niezmiennych. Nie jest jakąś powszechną cechą konstytucjonalizmu zamieszczanie takich klauzul niezmienności określonych zasad czy norm konstytucyjnych, ale nawet w konstytucjach państw, które je zawierają, są one z reguły różne i wywodzą się z jakichś odrębnych doświadczeń historycznych lub priorytetów, czy wartości, uznawanych za absolutnie podstawowe. Sam fakt ich występowania należy często do zespołu cech specyficznych konstytucji danego państwa, wraz i innymi jej cechami, takimi jak choćby treści jej preambuły (lub jej

${ }^{1}$ Można tu stawiać pytanie o relacje między określeniem demokratyczne państwo prawne i państwo demokratyczne, ale wydaje się, że w kontekście, o jakim tu mowa, wyrażają one podobne założenia, a przy tym zmiana zasad państwa prawa oznaczałaby uszczerbek dla państwa demokratycznego (zob. Komentár k Ustave..., 2009, 109-111). 
brak), szczególna systematyka albo struktura itp. Chociaż klauzula wieczności ma tu o tyle inny charakter, że jej ciężar materialny nie jest równy innym cechom specyficznym, ma bowiem znacznie dalej idące znaczenie. Jedną z bardziej znanych formuł tego rodzaju jest francuska zasada o niezmienności republikańskiej formy rządów ${ }^{2}$. Wspomnieć o niej wypada nie ze względu na jakąś szczególną treść tego zastrzeżenia (które w każdej konstytucji zależy od deklarowanych w niej wartości priorytetowych), choć wartości republikańskie były i są we Francji w sposób szczególny - ze względów choćby na historię demokracji tego kraju - cenione,

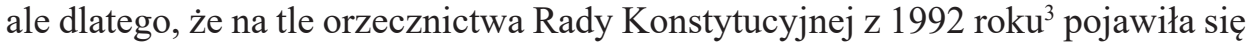
dyskusja o ważności takiej klauzuli konstytucyjnej w świetle zasady suwerenności narodu i zdolności suwerena do swobodnej zmiany ustroju konstytucyjnego. Dyskusja, jaka się na tym tle wywiązała w doktrynie francuskiej wskazuje, iż teza, że klauzula wieczności wiąże także suwerena nie jest aksjomatem, a więc mogłaby ustąpić wobec decyzji suwerena (Vedel 1993, 90).

Jeśli chodzi polską Konstytucję, nie wprowadza ona tak kategorycznej klauzuli niezmienności, jakkolwiek pewnej „dyscyplinie” odnośnie do zmian poddaje rozdz. I (Zasady podstawowe), II (Prawa i wolności) oraz XII (Tryb zmiany konstytucji), przewidując, że zmiana dokonana $\mathrm{w}$ zakresie tych rozdziałów ${ }^{4}$ może być na wniosek uprawnionych podmiotów (tych samych, które posiadają prawo inicjatywy ustawodawczej, tj. prezydent, senat i grupa co najmniej $1 / 5$ posłów) poddana referendum zatwierdzającemu zmianę. Widać tutaj raczej ten trend, który odwołuje się do decyzji suwerena. I to w sposób fakultatywny. Zapewne w praktyce grupa posłów przeciwna jakiejś konkretnej nowelizacji, dokonanej nawet przez kwalifikowaną większość z poparciem drugiej izby i prezydenta wykorzystałaby tę możliwość. Hipotetycznie jednak pełna zgoda parlamentu i głowy państwa wyłączyłaby suwerena od tej decyzji ${ }^{5}$.

Wspomniana wyżej francuska debata o warunkach usuwalności nieusuwalnej zasady oznacza, że problem trwałości klauzul niezmienności nie jest czysto teoretyczny. Wprowadzenie do czeskiej konstytucji tak zaporowej klauzuli także

${ }^{2}$ Art. 89 ust. 5 Konstytucji Republiki Francji z 1958 r.: „Republikańska forma rządów nie może być przedmiotem zmiany Konstytucji”.

${ }^{3} \mathrm{~W}$ związku z wprowadzeniem rozdziału poświęconego Wspólnotom Europejskim i UE, przy okazji ratyfikacji traktatu z Maastricht (sygn. 92-312 DC).

${ }^{4}$ Według Konstytucji RP z 1997 r.: ,,jeśli zmiana dotyczy...”, co było już poddane dyskusji, czy musi to być zmiana formalnie odnosząca się do przepisów zawartych w tych rozdziałach, czy wystarczy, jeśli zmiana dokonywana jest w innym rozdziale, ale materialnie wiąże się („,dotyczy”) $\mathrm{z}$ treściami owych trzech rozdziałów.

${ }^{5}$ Mimo wielu formalnych i nieformalnych prób zmiany Konstytucji z 1997 r., a nawet ogłaszania przez partie polityczne, i inne podmioty, projektów nowego aktu, tylko dwukrotnie dokonano zmiany Konstytucji RP i choć w jednym przypadku dotyczyło to przepisu rozdz. II (art. 55 o zakazie ekstradycji obywatela polskiego, zmieniony pod wpływem wprowadzenia europejskiego nakazu aresztowania), nie poddano go referendum (w razie zgłoszenia wniosku - referendum staje się obligatoryjne). 
zmusiło naukę prawa konstytucyjnego i orzecznictwo konstytucyjne tego kraju do bardzo zaawansowanego rozwoju doktryny w tej i podobnych kwestiach, o czym szczegółowo pisze M. Tomoszek (2018).

Z punktu widzenia polskiej praktyki, można by zatem niefrasobliwie powiedzieć: szczęśliwie w RP nie ma tego problemu, nie ma klauzuli wieczności, konstytucja nie deklaruje żadnych niezmiennych zasad, nauka i orzecznictwo nie muszą żmudnie ustalać, jakie są te nienaruszalne składniki państwa prawa (z punktu widzenia nowelizacji konstytucji), jakie z tego wynikają konsekwencje ich zmiany i czego w tej sytuacji nie wolno w konstytucji zmienić 6 . Ani nawet jak nie należy zasad konstytucji interpretować. I dotyczyć by to musiało nie tylko podstawowych praw i wolności, które są składową częścią jądra państwa prawnego, ale także sprawiedliwości społecznej, którą art. 2 konstytucji do tego jądra - jak się wydaje - zaliczył.

Otóż jednak nie. Ta „wygoda”, wynikająca z braku kategorycznego zastrzeżenia nieingerowania $\mathrm{w}$ istotę państwa prawnego, $\mathrm{z}$ punktu widzenia zasady, o której mowa (demokratycznego państwa prawnego), wydaje się nieopłacalna. Dlaczego? Jaką zaletę ma czeska formuła zawarta w art. 9, której brakłoby polskiej konstytucji? Otóż - nie ukrywając, że odpowiedź może być uznana za dyskusyjną i znajdzie się sporo argumentów, aby z nią skutecznie polemizować - warto jednak zauważyć, że ową zaletę można dostrzec w co najmniej w trzech aspektach.

Po pierwsze, zawarcie w Konstytucji przepisu analogicznego do art. 9 ust. 2, a także ust. 3 czeskiej Konstytucji, zmuszałoby doktrynę, zarówno prawną, jak polityczną, do zweryfikowania istoty demokratycznego państwa prawnego. Może to być nieco inne działanie, niż samo „odkodowanie” jej treści, dokonane $\mathrm{np}$. w toku orzecznictwa konstytucyjnego na potrzeby konkretnych rozstrzygnięć. Zidentyfikowanie istoty tej zasady ułatwiłoby, a może nawet zobiektywizowałoby ocenę, czy w drodze zmiany (lub interpretacji) konstytucji nastąpiło jej naruszenie poprzez naruszenie elementów składających się na tę istotę, powodując niedopuszczalność danej zmiany. O ile orzecznictwo na tle konkretnych sytuacji i na drodze konkretnych rozstrzygnięć buduje definicję państwa prawnego ad casu a casum, zaś doktryna buduje ją teoretycznie i na bazie porównawczej, o tyle analiza tego zagadnienia z punktu widzenia zasady niezmienności zasad konstytucyjnych, w dodatku niezmienności nakazanej przez konstytucję (czy inaczej mówiąc zmienności zakazanej), może przynieść korzyści na innej płaszczyźnie, a mianowicie wskazania nienaruszalności określonych zasad, jako swego rodzaju katalogu niedopuszczalnej nowelizacji i niedopuszczalnej interpretacji przepisów (zasad, norm, a nawet wartości) konstytucyjnych, bez których nie ma państwa

${ }^{6}$ Chociaż Banaszkiewicz $(2011,68)$ dostrzega fakt, że Konstytucja polska z 1997 r. zawiera namiastkę takich zasad, jako materialnego jądra konstytucji, np. w art. 30 (niezbywalna, nienaruszalna godność), to zarazem orzekanie o konstytucyjności zmian w tym zakresie uważa za „sprawę na razie egzotyczną". 
prawa. Zarazem wskazując, jakie zmiany i w jakim zakresie, w sferze tej zasady, mogą być jednak dopuszczalne, bo nie ucierpi na nich istota państwa prawnego. Przywoływany tu już wielokrotnie artykuł M. Tomoszka (2018), a także powoływana $\mathrm{w}$ jego tekście literatura czeska uświadamiają, jak wielki etap rozszyfrowania tego zagadnienia ma za sobą czeski konstytucjonalizm, któremu ustrojodawca zafundował art. 9 Konstytucji. Ukazują zresztą nie tylko katalog tych najważniejszych, definicyjnych i konstytutywnych, cech państwa prawnego, ale i ogrom wszelkich rozważań związanych z zaliczaniem, lub nie, określonych elementów do owego katalogu, ze wskazaniem zagrożeń płynących z określonych zmian (wiele mniej znaczących czy jedna przesądzająca?) itp. Tego w państwie, na które nie nałożono takiego konstytucyjnego kagańca, nie musi się dokonywać. I tak np. w Polsce interpretacja przepisu art. 187 o powoływaniu KRS nastąpiła na nieco nieprzygotowanym doktrynalnie gruncie, gdy wobec argumentu „nie jest napisane, kto wybiera przedstawicieli sędziów", mimo niemal powszechnego sprzeciwu nauki, jurysprudencji i znacznej części polityków wobec takiej interpretacji tego przepisu, krytycy pozostają jednak bezradni. To samo można odnieść do całej reszty ustawodawstwa, dotyczącego władzy sądowniczej i to jeszcze w sytuacji, w której nie dokonano w tym celu formalnej zmiany konstytucji.

Dlatego, kiedy szereg pozakonstytucyjnych zmian ustrojowych dotyka, narusza lub wręcz łamie zasadę państwa prawnego - konstytucyjne ostrzeżenie o niedopuszczalności takich zmian wydaje się niezwykle ważne. Pozwala unikać sytuacji, gdy niekonstytucyjnych zmian konstytucji dokonuje większość parlamentarna (rządząca) pod hasłem, że „większość może wszystko, bo jest większością". A to, że może ona wszystko argumentuje tym, iż otrzymała w wyborach legitymację do zmiany ustawodawstwa. Co więcej - i co może jeszcze gorsze - przeciwnicy tego argumentu odpowiadają, iż owszem, otrzymała legitymację do zmiany ustaw zwykłych (większością zwykłą), ale jednak nie do zmiany konstytucji, bo nie dostała wymaganej większości $2 / 3$. Ale gdyby dostała ową większość $2 / 3$, to czy już mogłaby dowolnie zmieniać konstytucję?

I to jest właśnie drugi aspekt zagadnienia. Bo otóż Konstytucja czeska stanowi: też nie! Tego, co jest istotą państwa prawa nie mogłaby zmienić nawet mając odpowiednią większość. I dlatego przepis ten wydaje się taki ważny. Jest to bowiem swoiste memento, że określonych zmian konstytucji nie może dokonywać nawet legitymizowana większość, w wystarczającej kwalifikowanej liczbie, i nawet $\mathrm{w}$ formie przewidzianej dla zmiany konstytucji ${ }^{7}$. Ale tu pojawiłoby się pytanie: większość nie, ale czy suweren bezpośrednio też nie mógłby? I w ten sposób powraca w pewnym sensie dylemat francuski, a mianowicie czy klauzula

${ }^{7}$ Zresztą art. 9 ust. 1 przypomina, ze zmiany mogą być dokonywane tylko w formie ustawy konstytucyjnej. Podobnie w polskiej Konstytucji bardzo szczegółowo określony jest tryb jej zmiany. Ale właśnie interpretacja przepisów konstytucji, jak cyt. art. 187 ust. 1 powoduje, że faktycznie konstytucję zmienia się ustawą zwykłą, jeszcze wyraźniej widać to w odniesieniu do art. 187 ust. 3 (przerwanie kadencji KRS), czy art. 183 ust. 3 (przerwanie kadencji I Prezesa SN). 
niezmienności ogranicza także suwerena. Odpowiedź w tym zakresie nie jest oczywista. Wydaje się, że w znacznej mierze zależy ona od nachylenia doktrynalnego w danym państwie, zwłaszcza w kontekście rozważań o wieczystości zasady państwa prawnego, gdy mogłoby być postawione pytanie, która wartość: suwerenność narodu czy rządy prawa (w znaczeniu państwa prawa) miałaby mieć pierwszeństwo? ${ }^{8}$ Sądząc z analizy M. Tomoszka, doktryna czeska podejmowała ten temat na gruncie rozważań związanych właśnie z art. 9 ust. 2 Konstytucji czeskiej.

Logiczną konsekwencją zakazu takiej zmiany konstytucji, która prowadziłaby do naruszenia istoty państwa prawnego, byłaby konieczność liczenia się z możliwością uchwalenia „niekonstytucyjnej ustawy konstytucyjnej” (zob. dalej).

A to prowadzi do kolejnego formalnoprawnego zagadnienia, które - jeśli w ustawie zasadniczej nie istnieje klauzula niezmienności danej zasady konstytucji - w praktyce nie występuje. Stąd w polskiej doktrynie tylko marginalnie podejmowano problem ewentualnej „konstytucyjności ustawy konstytucyjnej”, czy ściśle mówiąc na gruncie Konstytucji z 1997 roku, niekonstytucyjnej ustawy o zmianie konstytucji, a ewentualnie orzekania o konstytucyjności takiej zmiany (Tuleja, Szczurowski 2016, 1657, Nb 67) ${ }^{9}$. Wniosek w tym względzie - zresztą słuszny w obecnym stanie prawnym, gdy konstytucja nie zastrzega niezmienności danego przepisu (istoty danej zasady) - jest stosunkowo prosty, sądowa kontrola konstytucyjności ustawy o zmianie takiego przepisu w świetle art. 188 (kognicja TK) nie może być dokonywana, zaś w 235 (tryb zmiany konstytucji), co najwyżej w zakresie podmiotowym (prawo inicjatywy ) oraz procedury uchwalenia ustawy o zmianie konstytucji.

Co nie znaczy, że nawet tam, gdzie zasada wieczystości jest w konstytucji przewidziana, łatwo pogodzić się z faktycznym podjęciem przez sąd konstytucyjny orzekania w tym zakresie i wydanie orzeczenia o niezgodności takiej zmiany. Burzliwie zatem przyjęto w Republice Czeskiej pierwsze orzeczenie Sądu Konstytucyjnego o niekonstytucyjności ustawy konstytucyjnej (Koudelka 2011, 46-55). Wskazując, iż orzeczeniem tym Sąd ten ,,przekroczył Rubikon”, ponieważ „,wyszedł poza tradycyjnie rozumianą rolę sądownictwa konstytucyjnego, czyli ochronę konstytucyjności prawa stanowionego na poziomie norm o randze niższej niż konstytucja" (tamże, 47). Dało to także powód do rozważań o granicach aktywizmu sędziowskiego (Banaszkiewicz 2011). W tym pierwszym orzeczeniu, wywołanym skargą konstytucyjną jednego z posłów, rzecz dotyczyła ustawy konstytucyjnej o skróceniu kadencji Izby Poselskiej i był to nie pierwszy przypadek tego rodzaju procedury

${ }^{8}$ Taki problem był już także w literaturze polskiej rozważany, zob. m.in. Piotrowski (2017, 702-727), wprost także Machelon (2006, 150-170).

${ }^{9}$ Autorzy zauważają, iż ustawa o zmianie konstytucji jest „w naturalny sposób niezgodna z konstytucją", kontroli może więc podlegać tryb uchwalenia zmiany, także z punktu widzenia kompetencji do jej inicjowania. Podobną ocenę znajdziemy w pozostałych komentarzach do Konstytucji RP. 
w kraju, w którym brak było konstytucyjnego uprawnienia izby do samorozwiązania (skrócenia swojej kadencji), w tym drugi po rządami obowiązującej konstytucji, tyle, że wcześniej, w 1998 roku, zabieg taki nie był kwestionowany i stosowna ustawa konstytucyjna nie podlegała kontroli (zob. Koudelka 2011, 51). O ile wątpliwości w odniesieniu do tego konkretnego przypadku można podzielać, o tyle problem takiego orzecznictwa musi się pojawić w sytuacji zastrzeżenia niezmienności, i doktryna powinna być na nią przygotowana. Może nawet wtedy, gdy wcześniej podobnej zmiany nie poddawano kontroli. Nie przypadkiem trafnie zauważył B. Banaszkiewicz $(2011,68)$, w kontekście wcześniejszej uwagi o art. 30 konstytucji polskiej, ,zanim życie być może niespodziewanie postawi ją na porządku dziennym także u nas". Może więc nawet sama ustawa zasadnicza, deklarując zasadę niezmienności, powinna w tym zakresie być mniej oszczędna i w przepisach proceduralnych umieścić odpowiednią wskazówkę. Z tekstu M. Tomoszka czytelnik dowie się, jak reagują w ostateczności doktryna i orzecznictwo czeskie. Tu można jednak tylko dodać, że taka ochrona państwa prawa, jakiej udziela Konstytucja czeska wymaga, jak widać, wiele wysiłku intelektualnego w rozstrzygnięciu szeregu dylematów, jakich na tle tradycyjnych, historycznie ukształtowanych zasad państwa demokratycznego, dostarcza współczesność ,w państwie postnowoczesnym” (Chevellier 2014; Jaskiernia 2006, 10).

\section{2.}

Inny aspekt państwa prawnego, tak jak je rysuje Konstytucja czeska, wiąże się z rolą większości parlamentarnej (danej izby, przede wszystkim większości rządzącej, ale można te uwagi odnieść do każdej w danym momencie ukształtowanej większości podejmującej określoną decyzję). Już wyżej wspomniano, że w ostatnim czasie problem większości powraca często w polskich politycznych i prawniczych dyskusjach, zwłaszcza w związku z podejmowanymi decyzjami o charakterze ustrojowym. I chociaż wytaczane są istotne argumenty przeciw owym decyzjom, z reguły przyznaje się, że partia polityczna, która w wyniku wyborów uzyskała większość w parlamencie, ma prawo do ich podejmowania (osobną sprawą jest, już tu sygnalizowane, naruszanie zasad konstytucyjnych drogą ustaw zwykłych ${ }^{10}$ ).

I tu dochodzimy do kolejnego istotnego przepisu konstytucji czeskiej, którego wagę można docenić zwłaszcza wtedy, gdy się analogicznego we własnej konstytucji nie ma. Otóż chodzi o art. 6, w myśl którego „decyzje polityczne opierają się na woli większości”, ale „rozstrzygnięcia większości uwzględniają ochronę mniejszości". Nawet bardzo wąsko rozumiany ten przepis ${ }^{11}$ wskazuje, że

${ }^{10} \mathrm{~W}$ państwie demokratycznym taka sytuacja powinna być łatwo rozwiązywana poprzez orzecznictwo konstytucyjne, w Polsce istnieje z tym pewien problem, ale to inny temat (zob. Radziewicz, Tuleja 2017).

${ }^{11}$ To znaczy tylko jako odnoszący się do mniejszości typu etnicznego. 
większość nie może podejmować decyzji wyłącznie we własnym interesie. Nie wydaje się jednak, aby przepis ten musiał być koniecznie tak wąsko postrzegany i, jak się wydaje, należy go odczytywać tak, że uprawnienie większości do stanowienia prawa (czy podejmowania innych decyzji) nie może nie brać pod uwagę stanowiska mniejszości. Nie może nie uwzględniać jej poglądu (na określone rozwiązanie prawne), jej interesu (prawnego, politycznego), nie może eliminować jej z udziału w debacie dotyczącej danego rozstrzygnięcia, ani - np. w parlamencie - systemowo, a nawet cynicznie odrzucać jej wszystkich wniosków, poprawek, uwag [Ostatnio w Polsce uchwalano trzy istotne projekty ustrojowe jak najbardziej dotyczące państwa prawa, tj. niezależności sądów od władzy politycznej i niezawisłości sędziów, ponadto także prawa wyborczego, w taki sposób, że w komisjach wszystkie poprawki opozycji zostały odrzucone (w większości en bloc), wszystkie poprawki większości przyjęte, tylko pomyłka sprawiła jakiś wyjątek, tempo prac było ekspresowe. Uchwalanie poważnych ustaw ustrojowych, traktowanych przez uchwalającą większość, jako „reforma sądownictwa”, trwało ok. trzech tygodni od złożenia projektu do ogłoszenia ustawy ${ }^{12}$. Ponadto decyzje większości powinny być poddane kontroli sądów, zaś decyzje w zakresie stanowienia prawa - sądowi konstytucyjnemu. Te nie były].

Trudno tu też pominąc fakt, że przepis art. 6 czeskiej konstytucji uświadamia, a co najmniej podkreśla, inną jeszcze istotną okoliczność, że zarówno społeczeństwo (mówiąc bardzo doktrynalnie - suweren), jak i jego przedstawicielstwo w parlamencie, są pluralistyczne. Oznacza to, że ani większość obywateli nie eliminuje mniejszości, ani zwłaszcza większość rządząca nie eliminuje mniejszości, czyli opozycji. Większość nie ma monopolu na reprezentację, bo mniejszość jest też reprezentacją. Warto tu choćby skrótowo przywołać obszerną literaturę na temat demokracji większościowej, gdzie wyraźnie podkreśla się, że w wyniku technik wyborczych władzę oddaje się większości sztucznie wykreowanej ${ }^{13}$ i jeśli rządy nie są oparte na systemie konsensualnym, to w systemie politycznym musi znajdować się szereg zabezpieczeń przed nadużyciem władzy.

Art. 6 czeskiej Konstytucji to właśnie przypomina, a przy okazji wręcz namacalnie gwarantuje istotę pluralizmu społecznego i politycznego: nie wystarczy, aby mniejszość mogła sobie istnieć, ale musi być ona podmiotowo traktowana. Wydaje się więc, że wyrażenie w konstytucji owej relacji większości i mniejszości jest jedną z ważniejszych zasad składowych państwa prawnego. W cytowanym czeskim komentarzu wskazuje się, że konstytucja w tym artykule charakteryzuje relacje między dwiema opozycyjnymi „wolami głosowania”, zapewniając respekt dla praw mniejszości i swobody ich publicznego przejawiania (Klíma a kol. 2009, Komentár k Ustave..., 96-97). Jeśli potraktować ten problem nie tylko

${ }^{12} \mathrm{~W}$ dwóch przypadkach - ustawy o SN i nowelizacji ustawy o KRS - do chwili ogłoszenia weta Prezydenta, ale późniejsze wersje tych ustaw były równie sprawnie uchwalane.

${ }^{13}$ Lauvaux $(1994,7)$ prezentuje główne koncepcje demokracji większościowej, w tym ww. pogląd A. Lijpharta o większościach parlamentarnych. 
na płaszczyźnie funkcjonowania parlamentu, a zwłaszcza podejmowania decyzji, ale w szerszej perspektywie życia społecznego, artykuł 6 Konstytucji czeskiej jeszcze mocniej podkreśla aspekt relacji między większością i mniejszością, także w odniesieniu do wszelkich mniejszości społecznych.

3.

Oczywiście zasada demokratycznego państwa prawa przejawia się także w pozostałych zasadach ustrojowych Konstytucji czeskiej z 1993 roku. Truizmem byłoby ich wyliczanie. Wspomnieć więc wypada tylko dla porządku o zasadzie podziału władzy, zasadzie wolnych wyborów, zasadzie niezawisłości sądów i szeregu innych, stanowiących kanon państwa prawnego. Zatrzymać się wszakże pragnę na jednej z zasad, która wyrażona jest wprawdzie nieco en passant, ale znowu wydaje się bardzo ważna: to jest prawo do samorządu. Ono znowu wyrażone jest expressis verbis, nie trzeba dedukować z przepisów ani interpretacyjnie uznawać za oczywiste, bo ono w w art. 100 Konstytucji jest wyraźnie ustanowione: ,[j] ednostki samorządu terytorialnego są terytorialnymi społecznościami obywateli, które mają prawo do samorządu" (a tworzyć i znosić te jednostki można tylko ustawą konstytucyjną). Wydaje się to znowu ważne, i to nie tylko ze względu na znaczenie we współczesnym świecie prawa społeczności obywatelskich do samorządu, co w można traktować jako wyraz podzielenia władzy między państwo a obywateli. I nie chodzi tu o stworzenie tzw. „czwartej władzy” uzupełniającej trójpodział. Chodzi o prawo obywateli, których wspólnoty w myśl zasady subsydiarności nie w całości muszą być rządzone przez państwo, to jest przez administrację państwową, ale mają prawo samodecydowania o sobie, mają prawo same się rządzić. W duchu demokratycznego państwa prawnego można określić zakres tej samorządności, ale nie można jej ograniczyć tak, aby naruszyć istotę tego prawa.

4.

Trudno mówić o państwie prawa nie analizując podstawowych praw i wolności. Generalnie przepisy Karty podstawowych praw i wolności Republiki Czeskiej wcielają tę zasadę. Jest ona podstawowym składnikiem demokratycznego państwa prawnego i, jak chodzi o Konstytucję Republiki Czeskiej, dodatkowy wyraz daje temu cytowany już na wstępie art. 1, wiążąc ściśle rolę państwa prawa z poszanowaniem praw i wolności. Zresztą polska Konstytucja, która wprawdzie w tym miejscu preferuje sprawiedliwość społeczną (też zresztą mieszczącą się w kategorii praw człowieka), co do katalogu praw i wolności może wymaganiu państwa prawnego sprostać. Tym bardziej, że wskazuje na aspekt „przyrodzonej i niezbywalnej godności człowieka” jako ,źródła wolności i praw”, a jej nienaruszalność, poszanowanie i ochrona są obowiązkiem władzy. Jest to więc 
analogiczne podejście, jak w czeskiej konstytucji, tyle tylko, że bez owego zastrzeżenia klauzuli wieczności. Może ma w tym zakresie rację B. Banaszkiewicz wskazując, o czym już wcześniej wspomniano, że doszukiwać by się tu można także swoistej klauzuli wieczności. Ale problemowi praw i wolności poświęcono tak obszerną literaturę, że trudno tu podejmować dalej idące rozważania.

Z wyjątkiem dwu kwestii, o których warto wspomnieć. Otóż Karta podstawowych praw i wolności w art. 23 deklaruje prawo obywateli do oporu, formułując je następująco: ,[o]bywatele mają prawo do oporu wobec każdego, kto odrzucałby demokratyczny porządek praw człowieka i wolności podstawowych przyjętych w Karcie, jeśli działalność organów konstytucyjnych i zastosowanie środków ustawowych okażą się uniemożliwione”. Tym przepisem Karty Republika Czeska wpisuje się między te państwa, które konstytucyjnie uznają obywatelskie prawo do oporu, jak zwłaszcza te najbardziej znane: Francja z jej art. 2 Deklaracji Praw Człowieka i Obywatela z 1789 roku (prawo do „oporu przeciw uciskowi”) i Niemcy z art. 20 ust. 4 UZ (od 1968 r. „wszyscy Niemcy mają prawo do oporu..."), a także po transformacji np. państwa bałtyckie - Litwa, Łotwa i Estonia. Też Słowacja, której tekst art. 30 Konstytucji jest bardzo podobny do czeskiej wersji z Karty (jak się przypomina, źródłem przepisu może być słowacki projekt Karty jeszcze z okresu federacji).

Mimo historycznych i filozoficznych odniesień wobec prawa do oporu czy obywatelskiego nieposłuszeństwa (a może właśnie dlatego?), w doktrynie czeskiej dostrzec można pewną rezerwę wobec zasady zawartej w art. 23 Karty. Wydaje się, że brak jest liczniejszych, obszerniejszych opracowań tej problematyki (Kysela 2006; Černý 2015), a ponadto także jednolitego poglądu na istotę i zwłaszcza użyteczność tego przepisu. Tak więc jedni postrzegają prawo do oporu jako gwarancję niezmienności istoty państwa prawnego, inni są bardziej sceptyczni co do realnego jego znaczenia. W tej grupie Karel Klíma, autor cytowanego już wyżej Komentarza, ocenia art. 23 jako „raczej deklaratywne wyzwanie, niż normę o prawnie zdefiniowanych warunkach", a wobec faktu, że postanowienie to nie przewiduje ani nie wymaga konkretyzacji ustawowej, ma znaczenie na płaszczyźnie „polityczno-deklaracyjnej”, choć i ten autor zalicza prawo do oporu do katalogu gwarancji niezmienności zasady państwa prawnego (Klíma a kol. 2009, Komentáŕ k Ustave..., 1160-1161).

Być może bardziej realnie potraktowano by art. 23 Karty, gdyby - jak ostatnio w Polsce - pojawiały się w praktyce obywatelskiej odwołania do nieposłuszeństwa obywatelskiego, jego prawnych, historycznych czy filozoficznych koncepcji. Ale ponieważ owo nieposłuszeństwo nie ma żadnej podstawy prawnej (a przynajmniej się jej, jak na razie, nie wykazuje) na władzach porządkowych nie czyni to żadnego wrażenia, nie mają one bowiem do dyspozycji żadnego przepisu rozstrzygającego, czy Władysław Frasyniuk i wraz z nim inni, mogli bezkarnie siedzieć na trasie legalnego pochodu, czy też nie mogli. Zwłaszcza że sami siedzący nie kwestionują prawa władzy do ich ukarania, rozumując: możesz 
być w słusznej sprawie nieposłuszny prawu (np. blokować legalną demonstrację faszystowską), ale musisz ponieść za to karę, bo to blokowanie jest przez prawo zakazane. Być może, przy istnieniu konstytucyjnego prawa do oporu, taka kara nie groziłaby.

Oczywiście trudno tu mówić o koncepcji pełnej swobody każdego w realizacji prawa do oporu czy prawa obywatelskiego nieposłuszeństwa, bo było by to sugerowaniem raczej „obywatelskiej” anarchii i nieprzestrzegania prawa. Wspomniani autorzy opracowań o prawie do oporu w konstytucji czeskiej, J. Kysela i jego uczeń T. Černý, przeprowadzają analizę warunków funkcjonowania tego prawa, podejmując m.in. takie wątki jak: prawo indywidualne czy kolektywne (jak wielki kolektyw?), obywatelskie czy szersze, pasywne (odmowa np. płacenia podatków), czy aktywne (demonstracje, blokady), z użyciem siły, czy bez? A więc poszukują odpowiedzi, jakimi legalnymi środkami mogłoby być realizowane, z jakim odniesieniem do zasady proporcjonalności itd. (Černý 2015, 18-30). Jednak brak konstytucyjnego zakotwiczenia tego prawa - podobnie jak to jest w przypadku braku zastrzeżenia, że nie może podlegać zmianie istota państwa prawa - nie prowadzi ani do doktrynalnego, ani do ustawowego, ani wreszcie do orzeczniczego ustalenia zasad rządzących tym prawem, tak w zakresie jego wykorzystywania przez obywateli, jak i co do respektowania go przez państwo, chyba że częściowej odpowiedzi udzielą sądy rozpatrujące wykroczenia związane z obywatelskim nieposłuszeństwem. Odpowiedni przepis w konstytucji miałby zatem szansę zmusić państwo do stworzenia odpowiedniego jego „oprzyrządowania” prawnego, a być może wpłynąłby też na powstrzymywanie się od przyjmowania takich przepisów jak „cykliczne demonstracje”, wiedząc, że prawo pozwalałoby na ich legalne, również cykliczne, kontestowanie ${ }^{14}$.

Poza takimi przejawami prawa do oporu pojawiłyby się zapewne inne. Nie przypadkiem chyba w debacie polskiej przywoływana jest wynikająca $\mathrm{z}$ teorii Radbrucha idea niepodporządkowania się prawu, które łamie porządek demokratyczny i mogłoby być traktowane jako nieprawo. Właśnie bowiem w Polsce, o czym już wyżej wspomniano, szereg zastrzeżeń do konstytucyjności ustaw odnoszących się do władzy sądowniczej (TK, KRS, SN i sądów powszechnych) wywołuje opór wobec ich stosowania ${ }^{15}$. Nie przekłada się to jednak na urzędową, formalną weryfikację zachowania zasad państwa prawnego, bowiem brak jest ku temu właśnie tak deklaratywnych zasad, jak klauzula art. 9 ust. 2 i 3 Konstytucji Republiki Czeskiej i art. 23 jej Karty podstawowych praw i wolności.

${ }^{14} \mathrm{~W}$ nowych polskich przepisach o zgromadzeniach wprowadzono taką „ochronę” określonych ulicznych zgromadzeń publicznych, które nie mogą być zakłócane, a zatem we wskazanej odległości nie mogą się odbywać inne zgromadzenia; ustawa z 24 lipca 2015 r. Prawo o zgromadzeniach (Dz.U. 2015, poz. 1485).

${ }^{15} \mathrm{Z}$ takim uzasadnieniem kluby opozycyjne w Sejmie nie uczestniczyły w wyborze członków KRS na podstawie nowelizacji ustawy o KRS, a I Prezes SN zrzekła się przewodniczenia Radzie. 
Inny z przepisów czeskiej Karty, art. 22, czytany wraz z art. 5 konstytucji, tworzy całość, która - jak się wydaje - wykracza poza samą deklarację wolności tworzenia partii politycznych i ich celów działania, jakimi jest wpływanie na kształtowanie polityki państwa (jak w art. 11 polskiej Konstytucji). W art. 22 Karty odnajduje się bowiem ideę nie tylko owej konstytucyjnej deklaracji, ale także jej gwarancji ustawowej w zakresie zgodnej z ideą tej deklaracji wykładnią i - co najistotniejsze - stosowaniem. Artykuł ten stanowi, że ,ustawowa regulacja [...] oraz jej wykładnia i stosowanie muszą umożliwić i ochraniać swobodną konkurencję sil politycznych w demokratycznym społeczeństwie”. Krótko mówiąc, Konstytucja poręcza nie tylko zasadę pluralizmu politycznego, ale i zapewnia ochronę jej stosowania. Podobną ideę wyraża brytyjska formuła „rząd i opozycja jej królewskiej Mości”, które mają być równymi podmiotami, choć oczywiście czyni to językiem mocno historycznym. Gdyby próbować przełożyć te konstytucyjne gwarancje na praktykę polityczną, choćby na przykład w parlamencie, w procesie legislacyjnym, czy przy wszelkim innym podejmowaniu decyzji, mogłoby się okazać, że nie pozwalają one na tak dalece idące ignorowanie partii nienależących do rządzącej większości, jak to np. zdarza się często w polskim parlamencie, i to w obu izbach, o czym już wcześniej wspomniano w nieco innym kontekście.

5.

Na zakończenie warto wspomnieć o jeszcze jednym aspekcie czeskiej konstytucji, który choć gra znaczną rolę w przepisach poprawnej legislacji, dość rzadko jest zauważany, czy tylko wyodrębniany, jako ważny składnik państwa prawa i jako wyraz szacunku dla państwa prawa. To jest rola przepisów przejściowych. Przykład, o którym tu będzie wspomniane, dotyczy kwestii specyficznej Republiki Czeskiej, ale ma znaczenie ogólniejsze. Chodzi przede wszystkim o te przepisy przejściowe, które wiążą się ze zmianami strukturalnymi, spowodowanymi rozpadem Federacji Czechosłowackiej, jak pamiętamy - rozpadem nazywanym aksamitnym (w ramach aksamitnej rewolucji), bo też przeprowadzonym z wielką kulturą polityczną i prawną. I taki też charakter mają owe przepisy. Nie wykorzystywano tu okoliczności powstania odrębnego państwa czeskiego do przerywania kadencji, budowania od nowa struktur państwa. Przeciwnie: „w dniu wejścia w życie konstytucji Czeska Rada Narodowa staje się Izbą Poselską, której kadencja kończy się za 2,5 roku” (tj. 6.06.1996). I dalej: „Rząd Republiki Czeskiej mianowany po wyborach w 1992 r. i wykonujący swoją funkcję do dnia wejścia w życie konstytucji, uważa się za rząd mianowany na zasadach niniejszej konstytucji” [...], ,Sędziowie wszystkich sądów wykonujący funkcje do dnia wejścia konstytucji w życie, traktowani są jako sędziowie mianowani na zasadach Konstytucji Republiki Czeskiej"16 (żadnej okazji do zmiany!). Podobna kontynuacja

${ }^{16}$ Konstytucja, rozdz. VIII, Postanowienia przejściowe i końcowe, cyt. art. 106, 108, 111 (a także pozostałe). 
występuje w odniesieniu do porządku konstytucyjnego, chociaż oczywiście następują uchylenia aktów z okresu Federacji. Ale przecież sama Karta podstawowych praw i wolności, stanowiąca obok konstytucji fundament porządku konstytucyjnego Republiki Czeskiej, jest przeniesionym wolą nowego państwa - Republiki Czeskiej ${ }^{17}$ - aktem uchwalonym przez Zgromadzenie Federalne na podstawie projektów Czeskiej Rady Narodowej i Słowackiej Rady Narodowej, co expressis verbis wybrzmiewa w preambule do tego aktu. Zwrócenie uwagi na tę okoliczność wynika w pewnym sensie z owego polskiego punktu widzenia, który zasygnalizowany został już w tytule opracowania. W odniesieniu do tej kwestii, dlatego zwłaszcza, że przy reformowaniu sądownictwa, która to reforma tak mocno wzruszyła fundament państwa prawnego, o przepisach przejściowych zapomniano. To znaczy o tych, które się tam powinny znaleźć. Jeśli zatem - załóżmy z dobrą wolą - reforma, o której mowa wymagała istotnie wprowadzenia nowego wieku emerytalnego dla sędziów SN (czyli wieku ich przejścia w stan spoczynku) ${ }^{18}$, co spowodowało przerwanie konstytucyjnie określonej kadencji I Prezesa SN i perturbacje dla kilkudziesięciu innych sędziów SN, to w przepisach przejściowych nie znalazł się stosowny przepis oszczędzający tę kadencję i status tych pozostałych. Podobnie - gdy kadencję KRS postanowiono przekształcić z indywidualnej kadencji jej członków, w jednolitą (wspólną, jak napisano w ustawie) - tu także przepisy przejściowe nie zostały zaangażowane dla „naprawienia” szkody, jaką uczyniła ustawa, przerywając kadencje określone w konstytucji. To oczywiście nasuwa podejrzenie, że tu nie chodzi jedynie o potknięcie w zakresie techniki legislacyjnej. Ale to tym gorzej dla państwa prawa.

Jak zapewne dało się zauważyć, w niniejszym artykule założono, że spojrzenie na czeską problematykę państwa prawnego będzie dokonywane przez pryzmat doświadczenia polskiego. Tak to już bowiem jest, że zalety i wady konstytucji dostrzega się w okresie próby. Przez taką próbę przechodzi właśnie polska Konstytucja z 1997 roku, co pozwala dostrzec zalety Konstytucji Republiki Czeskiej z 1992 roku.

\section{BIBLIOGRAFIA}

Banaszkiewicz, Bolesław. 2011. „Demokracja pod specjalnym nadzorem. Uwagi o sędziowskim aktywizmie i granicach zmian konstytucji”. Forum Prawnicze 1 (3): 56- 68.

Černý, Tomáš. 2015. Právo na odpor. Právnicka Fakulta Univerzita Karlova, Praha (praca dyplomowa); https://is.cuni.cz/webapps/zzp/download/120177165,

Chevallier, Jaques. 2014. L'État post-moderne. Paris: L.G.D.J.

Jaskiernia, Jerzy. 2006. „Suwerenność narodu a koncepcja »państwa postsuwerennego«”. Państwo i Prawo 10: 43-59.

${ }^{17}$ Uchwałą Prezydium Czeskiej Rady Narodowej z dnia 16 grudnia 1992 r. (Sb. nr 1/1993).

${ }^{18} 65$ lat w miejsce obecnych 70; wprawdzie prezydent może wyrazić zgodę na dalsze sprawowanie funkcji, ale ma to charakter uznaniowy. 
Konstytucja Republiki Czeskiej, z dnia 16 grudnia 1992 roku (Sb. nr 1/93 ze zm.). Tłum M. Kruk. W Konstytucje państw Unii Europejskiej. Red. Wiesław Staśkiewicz. 2011. Warszawa: Wydawnictwo Sejmowe.

Klíma, Karel a kol. 2009. Komentář k Ústavě a Listině. 2. rozšířené vydání. Plzeń: Aleš Čeněk.

Morawska, Elżbieta. 2003. Klauzula państwa prawnego w Konstytucji RP na tle orzecznictwa Trybunału Konstytucyjnego. Toruń: Wydawnictwo Dom Organizatora.

Koudelka, Zdeněk. 2011. „Niekonstytucyjna ustawa konstytucyjna”. Tłum. B. Banaszkiewicz. Forum Prawnicze 1 (3): 46-55.

Kysela, Jan. 2006. Právo na odpor a občanská neposlušnost. Brno: Doplněk.

Lauvaux, Philippe. 1994. „La démocratie majoritaire: Conception et discussion d'un modèle polaire". Pouvoirs 85: 5-19.

Machelon, Jean-Pierre. 2006. Souveraineté et l'état de droit. W Les évolutions de la souveraineté. Ed. Dominique Maillard Desgrées du Loû. 157-172. Paris: L.G.D.J.

Piotrowski, Ryszard. 2017. Konstytucja i granice władzy suwerena. W Dwadzieścia lat obowiqzywania Konstytucji RP. Polska myśl konstytucyjna a międzynarodowe standardy demokratyczne. Red. Jerzy Jaskiernia, Kamil Spryszak. 702-727. Toruń: Wydawnictwo A. Marszałek.

Pavlíček, Václav. a kol. 2015. Ústavni právo a státověda. Díl 1: Ustavni právo České republiky. Leges, Praha.

Radziewicz, Piotr, Tuleja Piotr (red.). 2017. Konstytucyjny spór o granice zmian organizacji i zasad działania Trybunatu Konstytucyjnego, czerwiec 2015 - marzec 2016. Warszawa: Wolters Kluwer.

Tomoszek, Maxim. 2018. „Role podstatných náležitostí demokratického právního státu v ústavní praxi České republiky". Acta Universitatis Lodziensis. Folia Iuridica 84.

Tuleja, Piotr, Szczurowski Bartosz. 2016. Komentarz do art. 235. W Konstytucja RP. Red. Marek Safjan, Leszek Bosek. Duże Komentarze Becka. T. II. 1657, Nb 67. Warszawa: C.H. Beck.

Vedel, Georges. 1993. „Débat: Souveraineté et supraconstitutionnalité”. Pouvoirs 67: 79-97.

\title{
Maria Kruk
}

\section{PRINCIPLE OF A STATE GOVERNED BY THE RULE OF LAW IN THE CONSTITUTION OF THE CZECH REPUBLIC (A FEW COMMENTS FROM THE POINT OF VIEW OF POLAND'S EXPERIENCE)}

\begin{abstract}
The present considerations are devoted to the principle of a democratic state governed by the rule of law laid down in the Constitution of the Czech Republic of 1992: the way the principle is presented, its guarantees and protection that the Constitution provides for the essence of the state of law and the consequences of this regulation for both social and political life as well as for the development of the doctrine of constitutional law with respect to that issue. It is especially important that, apart from the declaration that the Czech Republic is a democratic state governed by the rule of law (Article 1 (1)), there is an additional reservation stipulating that any amendments violating this principle are impermissible (the eternity clause) and legal norms may not be interpreted in the way allowing such changes (Article 9 (2) and (3)). Moreover, other provisions of the Constitution connected with the principle are analysed, especially the rule that the majority decision-making shall take into consideration the interests of the minority (Article 6) and the citizens' right to resist formulated expresis verbis (Article 23 Charter of Fundamental Rights and Freedoms).

Keywords: principle of a state governed, Constitution of the Czech Republic of 1992, Constitution of the Republic of Poland of 1997, right to resist, civil disobedience, transitional provisions.
\end{abstract}

